\title{
Pengaruh deviden, hutang, harga saham terhadap profitabilitas pada perusahaan jasa subsektor transportasi
}

\author{
Widya Kartika*; Ester Hasiholan Lumban Gaol; Sri Damayanti Br Pandiangan
}

Jurusan Manajemen Keuangan, Fakultas Ekonomi, Universitas Prima Indonesia,Medan.

*E-mail korespondensi : widyakartika998@yahoo.com

\begin{abstract}
The purpose of the study being studied is to examine the impact of dividends, debt, share prices on profitability in the transportation sub-sector services on the IDX. The data collection method in this research is the sampling technique. The total specimens in the studied study were 6 specimens. The assessment technique used is the multiple linear regression techniques with multiple values. This study describes that dividend payments have a partial impact on profitability, as evidenced by the $t$ value of $2.639>2.055$ and has a sig value of $0.014<0.05$. Deb to equity ratio has no impact on profitability, this can be seen from the t-count of $-1,132<2,055$ and has a sig value of $0.268>0.05$. The share price has an impact on profitability, as evidenced by the t-count of $-2.163<2.055$ and a significant value of $0.040<0.05$. The $R^{2}$ test of 0.181 explains the weak relationship between the variable dividend payout ratio, debt to equity ratio, and share price on the profitability of $18.1 \%$, and the remaining $81.9 \%$ is influenced by other factors.
\end{abstract}

Keywords: Dividends, Debt, Share price, Profitability.

\begin{abstract}
Abstrak
Tujuan pada kajian yang dikaji bermaksud menguji dampak deviden, hutang, harga saham pada profitabilitas pada jasa sub sektor transportasi terdapat di BEI. Metode pengambilan data dalam penelitian ini adalah tehnik pengambilan sampel. Total spesimen pada kajian yang diteliti ialah 6 spesimen. Teknik pengkajian di gunakan yaitu teknik multiple linier regression berganda dengan nilai. Pengkajian ini mendeskripsikan bahawa pembayaran dividend berdampak parsial pada profitabilitas, dibuktikan melalui nilai t hitung sebesar 2,639>2,055 dan memiliki nilai $\mathrm{t}$ sig bernilai $0,014<0,05$. Debtto equity ratio tidak berdampak pada profitabilitas, hal ini di lihat dari t-hitung sebesar $-1,132<2,055$ dan memiliki nilai $t$ sig bernilai 0,268 >0.05. Harga saham berdampak kepada profitabillitas, dibuktikan melalui thitung sebesar $-2,163<2,055$ dan nilai signifikan sebesar $0,040<0.05$. Pada uji $\mathrm{R}^{2}$ sebesar 0,181 menerangkan hubungan yang lemah antara variabel dividen payout ratio, debt to equity ratio dan harga saham pada profitabilitas sebesar $18,1 \%$ dan sisanya $81,9 \%$ dipengaruhi dengan faktor lainnya.
\end{abstract}

Kata kunci : Deviden, Hutang, Harga saham, Profitabilitas

\section{PENDAHULUAN}

Saham adalah sejenis rekan tersistematis bahwasanya beberapa pengusaha serta penanam modal menjalankan negosiasi bisnis sekuritas pada beraneka peraturan sudah 
ditetap kan. Perinividu bisa melaksanakan perdagangan andil, terbilang penanam modal lain. Penguasa bertindak beroperasi menarik penanam modal luar dan penanam modal nasional dalam permodalan diIndonesia. Mengenai tersebut dapat memajukan sirkulasi aset diIndonesia dan memajukan perdagangan lokal. Profitabilitas yang tinggi juga dapat mendapat pengaruh yang besar dengan adanya hutang pada suatu perusahaan walaupun mengalami kenaikan hutang yang cukup banyak suatu perusahaan memungkinkan untuk mendapatkan keuntungan yang lebih yang dikarenakan berani mengambil resiko terhadap kedepan nya maka berpengaruh terhadap nilai saham menunjukkan eksistensi yang dimiliki perusahaan tersebut yang mampu bangkit dari tahun- tahun sebelumnya.Perusahaan transportasi bagian terpenting dalam perekonomian Indonesia. Transportasi merupakan kebutuhan masyarakat untuk memperlancar segala kegiatan (Syamsul Bakhri,dkk 2018). Permasalahan yang terdapat dalam kajian ini yaitu pada PT.AirAsia Indonesia Tbk (CMPP) terus mengalami penurunan secara berturut selama tiga tahun sampai pada akhir tahun 2018 profitabilitas perusahaan ini mengalami kenaikan sebesar Rp.907.025 yang dipengaruhi oleh tinggi nya harga saham yang dibuat oleh perusahaan tersebut dan daya tarik beli saham terhadap perusahaan tersebut. Akan tetapi ditahun 2019 perusahaan ini kembali mengalami penurunan profitabilitas yang drastis sebesar Rp.-935.942 dan harga saham yang tinggi tidak mampu meningkat profitabilitas perusahaan tersebut.

Menurut Sudana (2015:192) deviden adalah segmen melalui ketetapan upah perusahaan ,spesifik berhubungan pada pembiayaan dalam perindustrian, sebab tinggi rendahnya keuntungan nan dialokasikan berdampak banyak kecil nya keuntungan di tahan. Peraturan dividen ialah persentasi profit nan di bayar untuk pemilik kontribusi pada acuan bentuk laba tunai, pengamatan kestabilan keuntungan pada masa yang akan datang, pendistribusian kontribusi laba. Harmono (2009:12).

Penurunan profitabilitas disebabkan oleh faktor biaya operasional perusahaan perseroan dan melemahnya nilai tukar rupiah serta masalah yang terjadi pada akhir 2014 berdampak pada kinerja Pt. AirAsia Indonesia Tbk. Sehingga butuh waktu untuk bisa pulih dari masalah tersebut tersebut.

Alasan peneliti memilih perusahaan transportasi sebagai objek penelitian dikarenakan perusahaan transportasi mempunyai peranan penting dalam mempengaruhi kegiatan ekonomi, sehingga transportasi dapat dijadikan sebagai tolak ukur perkembangan ekonomi diindonesia. Penelitian ini bertujuan melakukan kajian empiris terhadap faktor-faktor yang mempengaruhi kebijakan deviden perusahaan, khususnya perusahaan transportasi yang berdaftar di BEI. Berdasarkan beberapa hasil peneliti terdahulu yang telah dijelaskan variabel tersebut belum memberikan hasil yang konsisten sehingga perlu diuji kembali. Berikut adalah beberapa perusahaan yang mengalami kenaikan dan penurunan hutang, deviden dan harga saham.Tinjauan Pustaka

\section{METODE}

\section{Jenis penelitian}

Jenis penelitian adalah Metode kuantitatif. Menurut sugiyono (2013: 19) yang menyatakan bahwa observasi beralaskan dalam prinsipfakta, dimanfaatkan dalam mengobservasi akan komunitas atau sample, pengumpulan statistik memerlukan perangkat 
kajian, observasi statistik berkarakter statistickuantitativ, bermaksud mengevaluasi asumsi nan sudah dialokasikan.

Teknik penyatuan statistik serta arsip dimana pengertian arsip ialah daftar kasus nan telah lampau.Laporan keuangan di pakai yaitu catatan finansial perusaahaan jasa terdaftar pada Bursa Efek Indonesia 2015-2019.

\section{Uji asumsi klasik}

\section{Uji normalitas}

Ghozali (2016: 154), uji normalitas berfungsi dalam mengevaluasi adakah pada tiperegresi, pengaruh penggangu atau resiidual mempunyai pembagian abnormal. Pada uji ini dilihat pada kajian diagram Probabilty plot serta analisis statistic

\section{Uji multikolonieritas}

Menurut Ghozali (2016: 103), uji multikololinieritas tujuannya menyelidiki adakah bentukregresi di dapatkan adanya hubungan antara variable independend. Multikolonieritas dilihat melalui jumlah tollerance ataupun variance inflation factor (VIP).

\section{Uji autokorelasi}

Menurut Ghozali (2016: 110), bertujuan mengevaluasi adakah pada modelregresi linier adakahhubungan pada kecurangan penggangu dalam t-1. Apabilla terjadinya hubungan akan dinamakannya masalahlautokorelasi modelregresi nan bagus ialah regreasi lepas dariautokorelasi.

\section{Uji heteroskedastiisitas}

Gozali(2016:134), bermanfaat dalam mengobservasi adakah pada modelregreasi terjadiinya ketidakserupaan residuevarience melaluipengamat dalam ke pengamat luar.

\section{Pengaruh variabel deviden terhadap profitabilitas}

Menurut Sudana (2015:192) deviden adalah segmen melalui ketetapan upah perusahaan,spesifik berhubungan pada pembiayaan dalam perindustrian, sebab tinggi rendahnya keuntungan nan dialokasikan berdampak banyak kecil nya keuntungan di tahan. Peraturan dividen ialah persentasi profit nan di bayar untuk pemilik kontribusi pada acuan bentuk laba tunai, pengamatan kestabilan keuntungan pada masa yang akan datang, pendistribusian kontribusi laba. Harmono (2009:12).

\section{Pengaruh variabel hutang terhadap profitabilitas}

Menurut Hartono dalam jurnal Maizah Rosira, Rilla Gantino (2017), mendeskripsikan bahwasanya pinjaman membawa dampak. Tingginya ketidakamanan dalam perindutrian, maka akan besar pula laba bersih diinginkan kompensasi pada tinggi nya risiko. Sartono (2000:218) pinjaman ialah seluruh tanggungan Perindustrian oleh golongan asing mesti terwujud, dimana pinjaman yaitu asal devisa/kreditur.

\section{Pengaruh variabel harga saham terhadap profitabilitas}

Menurut Bambang Riyanto(2013:240) harga sahham fakta survei komponen maupun 
kandidat perusahaan untuk membagi profit perusahaan tersebut dengan membagi dividen diantaranya. Menurut Jogianto(2008:197) harga suatu kontribusi berlaku dipasaran sahaam dengan waktu khususoleh permintaan dan penawaran sahaam bersangkutan dipasaran persediaan.

\section{Model penelitian}

Pengkajian yang diteliti merupakan kajian linear rangkap berfungsi mengetauhi hubungan serta dampak dari independend nan jumlah nya dua /lebihnya terhadap variabel dependen .rumusnya :

$$
\mathbf{Y}=\boldsymbol{\alpha}+\boldsymbol{\beta}_{1} \mathrm{X}_{1}+\boldsymbol{\beta}_{2} \mathrm{X}_{2}+\boldsymbol{\beta}_{3} \mathrm{X}_{3}+\mathbf{e}
$$

\section{Keterangan :}

$\begin{array}{ll}\mathrm{Y} & =\text { Profitabilitas } \\ \alpha & =\text { Konstanta } \\ \beta, \beta, \beta & =\text { Koefisien regresi } \\ \mathrm{X} 1 & =\text { Kebijakan deviden } \\ \mathrm{X} 2 & =\text { Kebijakan hutang } \\ \mathrm{X} 3 & =\text { Harga saham } \\ \mathrm{e} & =\text { Error }\end{array}$

\section{Koefesien determinasi}

Adjust $\left(\mathrm{R}^{2}\right)$ menyatakan untuk menghitung bagaimana jauhnya efektivitas bentuk pada mendeskripsikan variasi independen. Pada kajian empiiris didapat jumlah adjust $\mathrm{R}^{2}$ negatif, bahawa adjust $\mathrm{R}^{2}=0$, Sebagai analtis andaikan $\mathrm{R}^{2}=1$, sementara kuantitas $\mathrm{R}^{2}=0$ bahwa adjust $\mathrm{R}^{2}=1-\mathrm{k}$ atau $\mathrm{n}-\mathrm{k}$. Andaikan $\mathrm{k}>1$, jumlah adjustnya pasti minus. Menurut Ghonzali (2016:95).

\section{Pengujian hipotesis secara simultan(f)}

Kajian statistic (F) mengevaluasi kajian bahawa $\beta_{1}, \beta_{2}, \beta_{3}$ simultan serupa pada nol. Untuk mengetahui kajian diterima ataupun ditolak dilakukan dengan membandikan Ftabel dengan tahap keyakinan 95\%(a=5\%) Ghozali (2016:96).

\section{Pengujian hipotesis secara parsial $(t)$}

Ghozali(2016:97) kajian statistic (t) dasarnya mendeskripsikan bagaimana jauhnya dampak satu variable independen perindividual dengan menjelaskan variableindependend. Untuk mengetauhi observasi diterima ataupun ditolak dilakukan membandingkan jumlahFhitung serta Ftabel dengan tahap keyakinan 95\% $(\mathrm{a}=5 \%)$.

\section{Pembahasan hasil penelitian hasil regresi linier berganda}

Hasil pada model regresilinierr bergaanda mengenai $D P R, D E R$ serta Harga Saham pada profitabilitas. Berdasarkan hasil estimasi maka model regresi linear berganda yaitu: $Y=0.769+2.150 X 1+-419 X 2+0.000 X 3$ 
Tabel 1. Hasil regresi linear berganda

\begin{tabular}{lccc}
\hline \multirow{2}{*}{ Model } & \multicolumn{2}{c}{ Unstandardiz koefisien } & Standardiz koefisien \\
\cline { 2 - 4 } & B & Standard.Error & $\begin{array}{c}\text { Beta } \\
\text { (konstan) }\end{array}$ \\
DPR & .769 & .594 & .463 \\
1 & 2.150 & .815 & \\
DER & & & -.197 \\
HARGA_SAHAM & -.419 & .370 & -.386
\end{tabular}

Sumber : Data diolah, 2020

Nilai konstan senilai 0.769 bernilai positif artinya jika nilai variabel $D P R, D E R$ serta Harga Saham diasumsikan 0, profitabilitasnya naik senilai 0.769 .

Dividen Payout Ratio mempunyai koefisien regresi 2.150 positif menjelaskan bahwa dividen payout ratio berdampak positif pada profitabilitas. menunjukkan setiap kenaikan satuan variable Dividen Payout Ratio serta dugaan variabel lainnya kerap meninggikan laba bersih senilai 2.150 .

DER memiliki koefisien regresi senilai $-0,419$ benilai negative menggambarkan $D E R$ berpengaruh negatif terhadap profitabilitas. observasi menjlaskan ketika naiknya satuan $D E R$ pada dugaan varibael lainnya kerap merendahkan nilai profitabilitas -0.419 .

Variabel harga saham memiliki koefisien regresi sebesar 0.000 bernilai positif membuktikan bahwasanya harga saham berdampak positif pada laba bersih. menunjukkan bahwasanya kenaikan satuan variabel harga saham pada dugaan variabel lainnya kerap menaiikkan jumlah laba bersih senilai 0,000 .

\section{Pengujian hipotesis secara parsial (uji t)}

Tabel 2. Hasil uji parsial

\begin{tabular}{|c|c|c|c|c|c|}
\hline \multirow{2}{*}{ Model } & \multicolumn{2}{|c|}{ Unstandardiz koefisien } & \multirow{2}{*}{$\begin{array}{c}\begin{array}{c}\text { Standardiz } \\
\text { koefisien }\end{array} \\
\text { Beta } \\
\end{array}$} & \multirow[t]{2}{*}{$\mathbf{t}$} & \multirow[t]{2}{*}{ Sig. } \\
\hline & B & Std. Error & & & \\
\hline (konstan) & .769 & .594 & & 1.293 & .207 \\
\hline DPR & 2.150 & .815 & .463 & 2.639 & .014 \\
\hline \multicolumn{6}{|l|}{1} \\
\hline DER & -.419 & .370 & -.197 & -1.132 & .268 \\
\hline Harga Saham & .000 & .000 & -.386 & -2.163 & .040 \\
\hline
\end{tabular}

Sumber : Data diolah, 2020

Dividen Payout Ratio menghasilkan thitung 2.639 > 2.055, memiliki t-signifikan 0,014 $<0,05$. Menjelaskan bahawa Dividen Payout Ratio berdampak segmental kepada lababersih. Variabel DER menghasilkan thitungnyabernilai $-1.132<2.055$ dan memiliki nilai tsignifikan sebesar 0,268>0,055. maka DER secara parsial tiada dampak kepada profitabilitas. Variabel Harga Saham memiliki nilai t-hitung sebesar $-2.163<2.055$ dan nilai t_signifikan 
memiliki nilai $0,040<0,05$. Hal ini menunjukkan bahwa harga saham berpengaruh terhadap Profitabilitas.

\section{Pengujian hipotesis secara $\operatorname{simultan}($ Uji F )}

Kajian (F)guna mengevaluasi adakah variabel independent memberi dampak kepada variabel dependent.

Tabel 3. Hasil simultan

\begin{tabular}{llccccc}
\multicolumn{1}{c}{ Model } & Sum of Squares & Df & MeanSquare & F & Sig. \\
\hline Regresi & 21.714 & 3 & 7.238 & & \\
1 & Resiidual & 60.004 & 26 & 2.308 & 3.136 & $.042^{\mathrm{b}}$ \\
& Total & 81.718 & 29 & & & \\
\hline
\end{tabular}

Sumber : Data diolah, 2020

Berdasarkan Tabel 3 mendeskripikan bahawa Fhitungnya $3.136>$ Ftabelnya2,96, nilai f- signifikannya0,042<0,05 . Hal ini membuktikan bahwasanyaDividen PayoutRatio, DER, serta harga Saham berpengaruh simulltaan kepada Profitabilitas.

\section{Hasil uji koefisien determinasi}

Bertujuan guna memahami sebesarapa besarnya keahlian modelnya mengutarakan variableteriikat.

Tabel 4. Hasil uji koefisien determinasi

\begin{tabular}{llllll}
\hline Model & R & R Square & $\begin{array}{c}\text { AdjustR } \\
\text { Square }\end{array}$ & $\begin{array}{c}\text { Standard. } \\
\text { Errorof } \\
\text { theEstimasi }\end{array}$ & DW \\
\hline 1 & $.515^{\mathrm{a}}$ & .266 & .181 & 1.51916 & .621 \\
\hline
\end{tabular}

Sumber : Data diolah, 2020

Hasil Uji koefisiiendeterminasi ialah 0,181 yang menerangkan tingkat hubungan yang lemah antara variabel DPR,, DER dan Hargsa Saham pada Profitabilitas sebesar $18,1 \%$ dan sisanya $81,9 \%$ dipengaruhi variabel lainnya.

\section{KESIMPULAN DAN SARAN}

\section{Kesimpulan}

Manfaat dalam observasi yang telah diteliti deviden payout ratio, DER, harga saham secara parsial maupun simultan terhadap nilai perusahaan sebsektor transportasi yang terdapat dalam BEI.

Untuk variabel $D P R$ secara parsial berdampak relevan kepada profitabilitas subsektor transportasi periode 2015-2019. Variabel DER secara parsial tiada berdampak relevan kepada Profitabilitas Subsektor Traansportasi periode 2015-2019.Variabel harga saham 
berdampak relevan kepada profitabiliitas subsektor transportasi masa 2015-2019.Variabel $D P R, D E R$, serta harga saham berpengaruh simulltasn kepada Profitabilitas Subsektor Traansportasi periode 2015-2019. Koefisien determinasi sebesar 18,1\% dan sisanya 81,9\% dipengaruhi pada faktor lainnya tiada termasuk dalam pengkajian yang diteliti.

\section{Saran}

Sarannya dalam pengkajian yang diteliti yaitu: 1).Peneliti lebih lanjut melakukan kepada variable nan lebih luas. 2).Perindustrian yang di pakai untuk sampelnya dibatasi oleh perusaahaan subsektor transportasi maka perlunya dilaksanakannya observasi lebih lanjutnya menggunakan sample pengkajian yang berbeda.

\section{DAFTAR PUSTAKA}

Rudi,Irawan. (2012). Pengaruh hutang terhadap profitabilitas perusahaan telekomunikasi yang Go Public di BEI Periode 2006-2011. Skripsi thesis, Universitas Islam Negeri Sultan Syarif Kasim: Riau

Harmono. (2009). Manajemen keuangan. BumiAksara: Jakarta

Sudana,Imade. (2011). Teori \& praktik manajemen keuangan perusahaan. Erlangga: Jakarta Ghozali, Imam,(2013). Aplikasi analisis multivariate dengan program IBM SPSS 21.Ed 7. Universitas Diponogoro: Semarang

Sugiyono, (2014). Metode penelitian.CetakanKe-15. PT.Grasindo: Jakarta

Muhammad Nur Fauzi., \& Suhadak. (2015). Pengaruh Kebijakan deviden dan pertumbuhan perusahaan terhadap struktur modal dan profitabilitas (Studi pada sektor minning yang terdaftar di Bursa Efek Indonesia Periode 2011-2013).Jurnal Administrasi Bisnis, 24(1), $1-10$

Ramel Yanuarta Adan., \& Shinta Permata Sari. (2013). Pengaruh likuiditas, kebijakan hutang, dan aktivitas terhadap profitabilitas pada perusahaan manufaktur yang terdaftar di Bursa Efek Indonesia (BEI). Jurnal Kajian Manajemen Bisnis. 2(2), 73-84, DOI : https://doi.org/10.24036/jkmb.476400

Ni Kadek Venimas Citra Dewi., Wayan Ciptadan., \& I Ketut Kirya .(2015). Pengaruh Loanto Deposit Ratio (LDR), Loanto Asset Ratio (LAR), Debtto Equity Ratio(DER), dan Current Ratio(CR) Terhadap Profitabilitas(ROA). e-Journal Bisma Universitas Pendidikan Ganesha Jurusan Manajemen, 3, 1-10

Pande Widya Rahmadewi, Nyoman Abundanti. (2018). Pengaruh EPS, PER, CR, dan ROE terhadap harga saham di Bursa Efek Indonesia. E-Jurnal Manajemen, 7(4), 2106 2133, doi: https://doi.org/10.24843/EJMUNUD.2018.v07.i04.p14.

Ade Indah Wulan dari dan Ida Bagus Badjra.(2019). Pengaruh Profitabilitas Terhadap Harga Saham Pada Perusahaan LQ-45 di Bursa Efek Indonesia (BEI). Jurnal Manajemen, 8(9), 5722 - 5740, doi: https://doi.org/10.24843/EJMUNUD.2019.v08.i09.p18.

Fiona. Efendi., \& N. Ngatno. (2018). Pengaruh Return on Assets (ROA terhadap harga saham dengan Earning PerShare (EPS) sebagai intervening (Studi kasus pada perusahaan sub sektortekstil dan garmen yang terdaftar di Bursa Efek Indonesia Periode 2013-2016), Jurnal Administrasi Bisnis, 7(1), 1-9, https://doi.org/10.14710/jab.v7i1.22568

Kasmir. (2015).Analisis laporan keuangan. Cetakan Ke 8. PT.Raja Grafindo Persad: Jakarta 
Nofri Lianto.MH(2017). Pengaruh hutang terhadap profitabilitas (Studi pada Bank Panin Syariah Tahun 2013-2016). Undergraduate thesis, UIN Raden Intan Lampung: Lampung

Ria Esana dan Ari Darmawan .(2017). Pengaruh Kebijakan Dividen dan keputusan Investasi Terhadap nilai perusahaan serta dampaknya terhadap profitabilitas $t+1$ ( Studi pada sub sektor industri barang konsumsi yang terdaftar di BEI periode 2006-2016). Jurnal Administrasi Bisnis: 50(6), 201-2010

Suwandi, Greciana Mukti.(2018). Pengaruh profitabilitas terhadap nilai perusahaan dengan corporate social responsibility sebagai variabel intervening pada perusahaan pertambangan yang listing di BEI tahun 2014-2016/Greciana Mukti Suwandi. Diploma Thesis, Universitas Negeri Malang: Malang

Syamsul Bakhri, Erna Listyaningsih, Nurbaiti .(2018). Pengaruh likuiditas dan profitabilitas terhadap financial distress pada perusahaan transportasi yang terdaftar di bursa efek Indonesia Periode 2014-2016. Jurnal Riset Akuntansi dan Manajemen Malahayati, 7(1), 40-47, doi:https://doi.org/10.33024/jeram.v7i 1.2166 